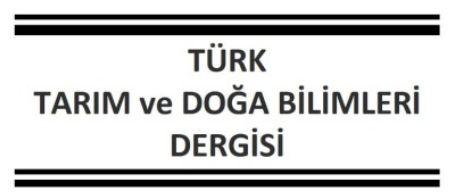

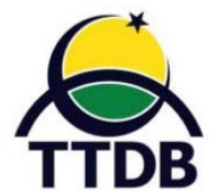

www.dergipark.gov.tr/turkjans

Araştırma Makalesi

\title{
Tarım İşletmelerinde Tarımsal Kredi Kullanım Durumunun Analizi
}

TURKISH

JOURNAL Of AGRICULTURAL and NATURAL SCIENCES

\author{
Arif SEMERCi
}

Çanakkale Onsekiz Mart Üniversitesi, Ziraat Fakültesi, Tarım Ekonomisi Bölümü, Çanakkale Sorumlu Yazar: arifsemerci@comu.edu.tr

Geliş Tarihi: 14.01.2021 Düzeltme Geliş Tarihi: 19.03.2021 Kabul Tarihi: 07.04.2021

\section{Öz}

Günümüzde tarım sektörünün işletme dışı sermaye talebi hızla artış göstermektedir. Bu durum özellikle; tarım sektöründe yer alan işletmelerin küçük ölçekli ve çok parçalı yapıya sahip olmaları, tasarruf düzeylerinin düşük olması yanında sermaye devir oranındaki düşüklüklerden kaynaklanmaktadır. Dünyanın önemli tarımsal üretim potansiyeline sahip olan ülkelerinden biri olan Türkiye'de tarım sektörüne sermaye ihtiyacının karşılanması amacıyla "0 ya da düşük faizli kredi” uygulaması yapılmaktadır. Bu amaca yönelik olarak Türkiye'de 2010-2020 yılları arasında T.C. Ziraat Bankası kanalıyla 4,5 milyon üreticiye toplam 258 milyar TL kredi sağlamıştır. Yapılan çalışmada; Türkiye'de yağlık ayçiçeği üretiminde 571, süt sığırcılığında 141, pamuk üretimde 136, kanola üretimde 83 ve çeltik üretiminde 74 adet tarım işletmesinden elde edilen veriler kullanılarak tarım işletmelerinin tarımsal kredi kullanım durumları incelenmiştir. Araştırma; Türkiye'de pamuk üreticilerinin $\% 60$, çeltik üreticilerin \%51, süt sığırcılığı işletmelerinin \%41, kanola üreticilerinin \%27 ve yağlık ayçiçeği üreticilerinin de bu faaliyet dalları için \%16 oranında tarımsal kredi kullandıklarını ortaya koymuştur. Ürün gruplarına göre tarımsal kredi kullanılan üretim alanlarının toplamdaki payı; pamukta $\% 60$, çeltikte $\% 59$, kanolada $\% 48$, yağlık ayçiçeğinde $\% 25$ olup, süt sığırcılığı işletmelerinde toplam borç içinde banka kaynaklı tarımsal kredilerin oranı ise \%60 düzeyindedir. Araştırmada incelenen işletmelerden tarımsal kredi kullananların ilk tercihinin T.C. Ziraat Bankası olduğu tespit edilmiştir. Zira Türkiye'de resmi olarak üreticilerin tarımsal kredi ihtiyacının karşılanmasında görevlendirilen devlet kurumu T.C. Ziraat Bankası'dır. Araştırma kapsamında yapılan istatistiki analizler işletme büyüklüklerinin arttıkça tarımsal krediye duyulan ihtiyacın da artış gösterdiğini ortaya koymuştur. Araştırma sonuçları; Türkiye'de tarımsal üretimin sürdürülebilir koşullarda devam edebilmesi için "0 faizli ya da uygun faizli tarımsal kredi" uygulamasının orta ve uzun vadede de mutlaka devam etmesi gerektiğini ortaya koymuştur.

Anahtar kelimeler: Tarımsal kredi, kredi kullanımı, süt sığırcılığı, bitkisel üretim, Türkiye.

\section{Analysis of Agricultural Credit Usage in Agricultural Enterprises}

\begin{abstract}
In today's world, the agricultural sector's need for external capital has been increasing rapidly. This need is mostly caused by reasons such as; agricultural enterprises mostly being small and medium scaled, and a low level of saving and low capital turnover ratio. Turkey is one of the most important agricultural producers in the world, and Turkey provides loans at a low or ' $0 \%$ ' interest rate to meet the agricultural sector's capital need. Thus, the Agricultural Bank of Turkey (Ziraat Bank) provided 258 billion TL in loans for 4,5 million agricultural producers between 2010 and 2020. In this study, the loan usage situation of agricultural enterprises were examined by the data gathered from 571 sunflower, 141 dairy cattle, 136 cotton, 83 canola, and 74 paddy enterprises. According to the research results, the loan usage ratio of the enterprises were as follows; $60 \%$ in cotton, $51 \%$ in paddy, $41 \%$ in dairy cattle, $27 \%$ in canola, and $16 \%$ in sunflower. Within the study, the Agricultural Bank was found to be the producers' first choice in loan usage. Also, it was found that enterprises' need for loans increased along with the size of the enterprises. The research results indicate that low and ' $0 \%$ ' loan practices should continue in order to provide sustainabilty in agricultural production.
\end{abstract}

Key words: Agricultural Loan, Loan Usage, Dairy Cattle, Crop Production, Turkey. 


\section{Giriş}

Dünya genelinde kırsal alanlarda yaşayan nüfusun en önemli gelir kaynağını tarımsal üretim faaliyetleri oluşturmaktadır. Tarım sektörü, ekonomide yer alan diğer sektörlere göre getirisi az, yönetilmesi zor ve sektörde yer alan nüfusun da sosyal refahı düşük bir görünüm sergilemesi nedeniyle, korunan ve desteklenen sektörlerin başında gelmektedir. Günümüzde, çağdaş tarıma destek veren geniş tedarik ve hizmet zinciri önemli ölçüde sermaye gerektirmektedir. Bu açıdan bugün tarım, sermaye piyasalarına dayanan diğer iş kollarından farklı bir yapıda değildir.

İşletmelerde üretilen girdiler yerine dışarıdan satın alınan girdi kullanımının devam etmesi, tarımsal işletme büyüklüklerinin artması ve tarımda artan uzmanlaşma, günümüz çiftçisinin sermaye ve kredi ihtiyaçlarının artmasına neden olmuştur. Üreticiler etkili bir üretim yapabilmek için işletme büyüklüklerini yükseltip satın aldıkları mal ve hizmetlerin hacmini artırırken birçok üretici daha büyük oranlarda ödünç sermaye kullanımının karlı olduğunu bilmektedirler. Tarımsal kredi amacına uygun olarak kullanıldığında, tarım işletmelerinde verimliliğin ve kazancın artırılmasına yardımcı olmaktadır (Doll ve Orazem, 2005).

Tarımsal krediler; üreticilerin mali güçlerini artırmak, işletme sermayesi temin etmek, işletmelerin etkin ve karlı çalışmalarını sağlamak yanında, verimlilik yoluyla gelir artışlarını gerçekleştirmek amacıyla verilmektedir (Inan, 2016).

Tarım sektöründe finansman kaynakları kurumsal olan ve kurumsal olmayan olmak üzere iki ana grupta değerlendirilmektedir. Kurumsal finans kaynakları; kamu kredi kuruluşları, tarım kredi kooperatifleri, özel kredi kuruluşları ve merkez bankaları şeklinde gruplandırılmaktadır. Kurumsal olmayan kaynaklar ise; şahısların birbirlerinden aldıkları borçlar, ürün toplayıcıları veya borç karşılığı ürünün baştan satılması gibi işlemler olarak ifade edilebilir. (Çetin, 2014). Bununla birlikte günümüzde alternatif finans yöntemleri olarak leasing (finansal kiralama) ve faktoring işlemleri de yapılabilmektedir (Vural, 2017).

Türkiye'de tarımsal üretimin devamlılığı bağlamında işletmelerin finansman taleplerinin karşılanması için dönem dönem farklı politikalar uygulanmaktadır. Ülkede düşük faizli yıllık tarımsal krediler son on beş yılda 4,3 milyar TL'den yaklaşık 40 milyar TL'ye ulaşmış ve bu kredilerin dönüş oranları yüzde 40'lardan yaklaşık yüzde 100 'e yükselmiş olup, sulama yatırım ve projelerine hibe ve sıfır faizli kredisi desteği verilmektedir. Tarım sektöründe tarımsal yatırım ve işletmecilik giderlerinin sağlanması amaçlı kullanılan tarımsal kredilerde cari faiz oranları 2003 öncesinde yüzde 70'lerde iken son yıllarda farklılık göstererek yüzde 8-10’lara düşmüştür (Yavuz ve Dilek, 2019).

Bankacılık Düzenleme ve Denetleme Kurumu (BDDK) verilerine göre, 2019 sonunda 107,8 milyar TL olan Türk bankacılık sektörünün tarım alanında kullandırdığı kredi miktarı bakiyesi, 2020 yılının Temmuz ayı sonunda 121,8 milyar TL'ye ulaşmıştır. Tarımsal finansman bakımından ilk sırada yer alan T.C. Ziraat Bankası, 2010-2020 döneminde tarımsal üretime yönelik olarak 4,5 milyon üreticiye toplam 258 milyar TL kredi sağlamıştır. T.C. Ziraat Bankası tarafından kullandırılan tarım kredilerinde Hazine ve Maliye Bakanlığı'nın üreticilere güçlü faiz desteği bulunmakla birlikte, bu faiz desteği ile üreticilere yansıyan faiz oranlarının bazı üretim konularında sıfıra kadar düşmektedir (TRT, 2020).

Bu çalışmada; Türkiye'nin güneyinde yer alan Hatay ilinde 141 süt sığırcılığı işletmesinden ve 136 pamuk üretim işletmesinden, ülkenin Avrupa kesimini oluşturan Trakya'daki 571 yağlık ayçiçeği üretim işletmesinden, ülkenin Marmara Bölgesi'nde yer alan ve Trakya'nın bir kısmını oluşturan Çanakkale ilindeki 74 çeltik üretim işletmesi ile 83 kanola üretim işletmesinden elde edilen veriler yardımıyla üreticilerin bu ürünlerin üretiminde tarımsal kredi kullanım düzeyleri incelenmiştir. Araştırmada elde edilen veriler diğer araştırma bulgularıyla karşılaştırmalı olarak analiz edilerek yorumlarda bulunulmuştur.

Tarımda kredi kullanımı üretim miktarının, verimliliğin, girdi kullanım etkinliğinin ve nihayetinde tarımsal gelirin artırılması için oldukça önemlidir. Ancak dünya genelinde üreticilerin tarımsal krediye ulaşımı ve kullanımlarına yönelik araştırmaların yetersiz kaldığı görülmektedir (Kumar ve ark., 2007; Kuwornu ve ark., 2012; Elias ve ark., 2015; Hananu ve ark., 2015; Saqip ve ark., 2017). Sürdürülebilir tarımsal üretim ve değerlendirme sürecinde ise; kredi, teşvik, hibe gibi farklı destekleme araçlarıyla sektörün korunması zorunluluk arz etmektedir. Duval (2003) tarımsal finans ve kredi altyapısı konusunda araştırma yapmıştır. Jouault ve Featherstone (2006) bankalar tarafından üreticilere sağlanan tarımsal kredileri üzerine çalışma yürütmüştür. Katchova (2005) çalışmasında "2001 Tarımsal Kaynak Yönetimi Çalışması (ARMS)"ndan elde edilen çiftlik düzeyindeki verilerden yararlanarak tarımsal krediler üretici yönünden incelenmiştir. Sebopetji ve Belete (2009) yapmış oldukları araştırmada; tarımsal işletmecilik deneyimi, cinsiyet ve medeni durum faktörlerinin üreticilerin kredi kullanım kararı üzerinde pozitif yönlü etkisi olduğu, çiftçilerin yaşı, eğitim düzeyi ve çiftçi derneklerine üyelik faktörlerinin ise negatif yönlü etkilediği sonucuna varmışlardır. Ljioma ve Osondu (2015) tarımsal kredi kaynakları ve çiftçiler tarafından kazanılan 
tarımsal kredi edinimlerinin belirlenmesi, Mitra ve Prodhan (2018) ise domates üreticilerinin krediye erişimini belirleyen faktörlerin tespit edilmesi üzerine araştırmada bulunmuşlardır.

Koç ve ark. (2019) tarafından yapılan bir çalışmada Türkiye'de uygulanmakta olan tarım kredilerindeki \%1'lik bir artışın, hektar başına tarımsal katma değerde ortalama yüzde 0.17 artış sağladığı, doğrudan etki ve yayılma etkisinin de \%0.12 olduğu tespit edilmiştir. Tarım kredilerinin aksine, hükümet desteklerindeki \%1'lik artışın, karma doğrudan ve yayılma etkileri yaratarak, Türkiye'de hektar başına tarımsal katma değerinde genel olarak \%0.13 azalmaya neden olduğu sonucuna varmışlardır.

Son dönemde dünya genelinde tarımsal üretimin artırılması ve tarım işletmelerin daha güçlü bir yapıya kavuşmalarını sağlamak için tarım sektörüne yönelik olarak verilen finansal desteklerin (kredilerin) ülke ve işletme boyutunda incelenmesine yönelik olarak bir çok ülkede çalışmalar yapıldığı anlaşılmaktadır (Andriushchenko ve ark., 2019; Boldyreva ve ark., 2020; Mamatzakis ve Staikouras, 2020; Moss ve Suh, 2020; OECD, 2020; Tetyana ve ark., 2020; Yan, 2020). Bununla birlikte, tarımsal üretimde işletme bazında kredi kullanımına ilişkin yapılan çalışmalara ait bilgiler, bulgular ve tartışma bölümünde ayrıntılı ve karşılaştırmalı analiz yapılarak verilmiştir.

\section{Materyal ve Metot}

Yapılan araştırmalarda; yağlık ayçiçeği üretimine ait veriler Türkiye'nin Trakya kesimi oluşturan Edirne, Kırklareli, Tekirdağ illeri ile Çanakkale ve İstanbul illerinin Avrupa yakasında kalan yerleşim birimlerinde yer alan 2008-2009 üretim ve pazarlama döneminde 571 işletmeden, süt sığırcılığı verileri 2013-2014 yılında Hatay ilinde 141 süt sığırcılığı işletmesinden, pamuk verileri yine Hatay ilinde 2017 yılı üretim döneminde 136 tarım işletmesinden, çeltik verileri 2018 yılı üretim döneminde Çanakkale ilinde yer alan 74 tarım işletmesinden ve kanola verileri ise 2018 yılında Çanakkale ilinde yer alan 83 tarım işletmesinden elde edilmiştir. Yapılan çalışmada araştırma konularıyla ilgili olarak yurtiçi ve yurtdışında yayınlanan makaleler incelenmiş, hazırlanan raporlar ve diğer yayınlardan da geniş ölçüde faydalanılmıştır.

Yağlık ayçiçeği, pamuk, çeltik ve süt sığırcılığı faaliyetleri için yapılan araştırmalarda uygulanan anket sayısının belirlenmesinde Tabakalı Örnekleme Yöntemlerinden "Neyman Yöntemi" kullanılmıştır (Yamane, 1967).

$$
n=\frac{[\Sigma(\text { Nh Sh })]^{2}}{N^{2} D^{2}+\Sigma\left[N h(S h)^{2}\right]}
$$

$n=$ Örnek Hacmi

$N_{h}=h^{\prime} ı n c ı$ tabakadaki birim sayısı (frekans)

$S_{h}=h^{\prime} ı n c ı$ tabakanın standart sapması

$N=$ Toplam birim sayıs

$S=$ Standart Sapma

$N=$ Örnekleme Çerçevesine Ait Toplam Birim Sayısı

$D=d / z$

$d=$ ortalamadan belirli bir oranda (\%1-\%5-\%10) sapmayı,

$z=t$ - dağılım çizelgesinde ( $N$-1) serbestlik derecesi ve belirli bir güven sınırına (\%90-\%95-\%99) ait " $t$ değeri"ni ifade etmektedir.

Örnek hacminin tabakalara dağıtılmasında aşağıda belirtilen formül kullanılmıştır (Çiçek ve Erkan, 1996).

$n=N h S h * n / \Sigma N h S h$

Yağlık ayçiçeği araştırmasında anket sayısının belirlenmesinde \%95 güven aralığı ve \%1 ortalamadan sapma dikkate alınmış ve 571 anket uygulanmıştır. Yağlık ayçiçeğinde işletme büyüklük grupları şöyle oluşmuştur: < 20 da (46 işletme), 2039.9 da arası (109 işletme), 40-59.9 da arası (109 işletme), 60-99 da arası (117 işletme), 100-149 da arası (94 işletme) ve 150 da ve üzeri (96 işletme) (Şahin et al, 2010). Pamuk araştırması kapsamında \%95 Güven Aralığı ve \%5 ortalamadan sapma ile 136 işletmede pamuk üretimine yönelik anket uygulaması gerçekleştirilmiştir. İşletmeler $<100$ da (63 işletme) ve >100 da (73 işletme) olmak üzere iki büyüklük grubuna ayrılmışlardır (Semerci ve Çelik, 2017). Süt sığırcılığı araştırmasında örnek hacminin belirlenmesinde \%3.5 ortalamadan sapma (hata payı), \%95 güven sınırları içerisinde çalışılmış olup, araştırmada 141 işletmede anket uygulaması yapılmıştır. İşletmeler süt sığırı varlığı; 5 baş ve altı ( 27 işletme), 6-10 baş ( 32 işletme) ve 11 baş ve üzeri (82 işletme) olmak üzere 3 büyüklük grubunda değerlendirilmiştir (Semerci et al, 2014 ). Kanola araştırmasında ise "Tam Sayım Yöntemi" kullanılarak 83 işletmede anket uygulaması yapılmıştır İşletmeler $<40$ da (44 işletme) ve $>40$ da ve üzeri (39 işletme) olmak üzere 2 grupta değerlendirilmiştir (Semerci, 2019). Çeltik araştırmasında \%99 güven aralığı ve \%5 ortalamadan sapma ile belirlenen 74 adet işletmede anket uygulaması gerçekleştirilmiştir. Çeltik üreten işletmeler; <=25 da (9 işletme), <=50 da (9 işletme), $<=100$ da (17 işletme), <=200 da (20 işletme) ve >=200 da (19 işletme) olmak üzere 5 büyüklük grubunda değerlendirilmiştir (Semerci ve Everest, 2020).

Çalışmada, incelenen işletmeler kredi kullanan işletmeler ve kredi kullanmayan işletmeler olmak 
üzere 2 ana gruba ayrılmıştır. Belirlenen 2 ana grup arasında (bağımsız örneklem grubu arasında); süt sığırcılığı faaliyetinde işletme başına ortalama sağmal inek varlığı ve süt verim değerleri arasında, bitkisel üretimde ise işletme başına ortalama değerler dikkate alınarak; kanolada birim alandan elde edilen verim $(\mathrm{kg} / \mathrm{da})$ ve üretim alanı $(\mathrm{da})$, çeltik üretiminde üreticilerin eğitim durumu (yıl), yağlık ayçiçeğinde üreticilerin eğitim durumu (yıl) ve yağlık ayçiçeği üretim alanı (da) ile pamukta birim alandan elde edilen verim $(\mathrm{kg} / \mathrm{da})$ ve üretim alanı (da) değerleri arasındaki farklılıkların belirlenmesinde "T-Test"den yararlanılmıştır. Bilindiği üzere "t-testi" nümerik (sürekli) değişkenlerin (ya da grupların) arasında istatistiki olarak anlamlı bir fark olup olmadığını test etmek, ya da gözlenen ortalama değerin varsayılan ya da öngörülen (ya da önceki araştırmalarda elde edilen) değerden farklı olup olmadığını tespit etmek için kullanılmaktadır.
Analizlerde kullanılan verilerin normal dağılıma uygunluğu "Shapiro-Wilks Test" ile test edilmiştir (Green et.al., 2000; Gujarati, 2009).

\section{Bulgular ve Tartışma Süt sığırcılığı faaliyeti}

Süt sığırcılığı faaliyetiyle ilgili yapılan araştırmada kullanılan veriler, tabakalı tesadüfi örnekleme yöntemi ile belirlenen 24 yerleşim birimindeki 141 süt sığırcılığı işletmesinden elde edilmiştir. İşletmelerde ortalama arazi büyüklüğü $58.20 \mathrm{da}$, yem bitkileri ekim alanının payı ise \%31.07 olarak belirlenmiştir. Araştırma kapsamındaki işletmelerde ortalama sığır sayısı 11.04 baş, sağmal inek sayısı ise 4.87 baştır. İncelenen süt sığırcılığı işletmelerinin işletme büyüklüklerine göre kredi kullanım kaynakları Çizelge 1'de verilmiştir.

Çizelge 1. İşletme büyüklüklerine göre süt sığırcılığı işletmelerinin kredi kaynakları

\begin{tabular}{|c|c|c|c|c|}
\hline Kredi Kaynakları & 1.Tabaka & 2.Tabaka & 3.Tabaka & Toplam \\
\hline Bankalar & 6 & 7 & 43 & 56 \\
\hline Tabakadaki İşletme Sayısı & 27 & 32 & 82 & 141 \\
\hline Рауı (\%) & 22.22 & 21.88 & 52.44 & 39.72 \\
\hline Yem Bayileri & 12 & 16 & 55 & 73 \\
\hline Tabakadaki İşletme Sayısı & 27 & 32 & 82 & 141 \\
\hline Рayı (\%) & 44.44 & 50.00 & 67.07 & 51.77 \\
\hline Tarım Kredi Kooperatifleri & - & 1 & 2 & 3 \\
\hline Tabakadaki İşletme Sayısı & 27 & 32 & 82 & 141 \\
\hline Рауı (\%) & 0.00 & 3.13 & 2.44 & 2.13 \\
\hline Şahıslar & 0 & 1 & 2 & 3 \\
\hline Tabakadaki İşletme Sayısı & 27 & 32 & 82 & 141 \\
\hline Рауı (\%) & 0.00 & 3.13 & 2.44 & 2.13 \\
\hline Toplam İşl. Say. & 18 & 25 & 102 & 135 \\
\hline
\end{tabular}

Süt sığırcılığı faaliyetine ilişkin olarak işletmelerin 2013 yılı itibariyle borçları 886,000 TL olarak hesaplanmıştır. İncelenen işletmelerde kullanılan dış kaynakların başında ise Ziraat Bankası gelmektedir (\%58.08). Zira işletmelerin borçlarında Çizelge 2. Süt sığırcılığı işletmelerinin kredi kullanım durumu en önemli payı damızlık olarak alınan düvelerin ve ineklerin borçları oluşturmaktadır. Kredi kullanımında ikinci sırayı \%35'lik pay ile yem alım masrafları gelmektedir (Çizelge 2). 


\begin{tabular}{lrccr}
\hline $\begin{array}{l}\text { Kredi } \\
\text { Kaynakları }\end{array}$ & $\begin{array}{r}\text { Iş̧letme } \\
\text { Sayısı }\end{array}$ & $\begin{array}{c}\text { Toplam } \\
\text { (TL) }\end{array}$ & $\begin{array}{c}\text { Işletme } \\
\text { Ortalaması } \\
\text { (TL) }\end{array}$ & $\begin{array}{c}\text { Pay } \\
(\%)\end{array}$ \\
\hline Bankalar & 56 & 533,600 & 9,529 & 60.23 \\
Yem Bayileri & 73 & 313,150 & 4,290 & 35.34 \\
Tar.Kredi & 3 & 24,000 & 8,000 & 2.71 \\
Koop. & 3 & 15,250 & 5,083 & 1.72 \\
Şahıslar & 135 & 886,000 & 6,563 & 100.00 \\
Toplam & & & &
\end{tabular}

Yapılan araştırmada incelenen işletmelerde işletme başına kredi kullanımından dolayı oluşan ortalama borç miktarı 6,562.96 TL olarak hesaplanmıştır. Hatay ilinde süt sığırcılığı ile ilgilenen işletmelerde yem bitkileri üretiminin toplam arazi varlığı içindeki payı önemli bulunmuş olmasına rağmen süt sığırcılığı faaliyetlerinin sürdürülebilmesi için gerekli olan süt yeminin büyük bir kısmını işletmeler dışarıdan sağlarken, kaba yem ihtiyacı önemli miktarda işletme içinden karşılanmaya çalışılmaktadır.

Süt sığırcılığı işletmelerinde kredi kullanan işletmeler ile kredi kullanmayan işletmeler arasında sağmal inek başına elde edilen süt verim değerleri bakımından istatistiki yönden \%1 düzeyinde farklılık göstermektedir. Çizelge 3'te verilen test sonuçlarına göre kredi kullanan işletmelerde sağmal inek başına elde edilen süt verim değeri $(5,200 \mathrm{lt} / \mathrm{yıl}) \mathrm{kredi}$ kullanmayan işletmelere göre $(5,717$ lt/yıl) daha yüksek düzeydedir.

Çizelge 3. Süt sığırcılığı işletmelerinde kredi kullanım durumlarına göre sağmal inek başına süt verim değerlerinin karşılaştırılması (t-testi sonuçları)

\begin{tabular}{lcccccc}
\hline Kredi Kullanım Durumu & $\mathrm{N}$ & Mean $(\bar{x})$ & Std.Dev. & df & t value & Sig. (p) \\
\hline Kredi Kullanmayan İşletmeler & 85 & 5200.72 & 783.90 & & & \\
Kredi Kullanan İşletmeler & 56 & 5717.24 & 1015.26 & & -3.40 & 0.001 \\
\hline
\end{tabular}

Süt sığırcılığı işletmelerinde kredi kullanan işletmelerdeki sağmal inek varlığı kredi kullanmayan işletmelere göre \%1 düzeyinde farklılık göstermektedir. Çizelge 4'teki test sonuçlarına göre kredi kullanan işletmelerde ortalama sağmal inek varlığı (yaklaşık 7 baş) kredi kullanmayan işletmelere göre (yaklaşık 4 baş) daha yüksek düzeydedir.

Çizelge 4. Süt sığırcılığı işletmelerinde kredi kullanım durumlarına göre sağmal inek varlığının karşılaştırılması (t-testi sonuçları)

\begin{tabular}{|c|c|c|c|c|c|c|}
\hline Kredi Kullanım Durumu & $\mathrm{N}$ & Mean $(\bar{x})$ & Std.Dev. & $d f$ & $\mathrm{t}$ value & Sig. (p) \\
\hline Kredi Kullanmayan İşletmeler & 85 & 3.69 & 1.76 & \multirow[b]{2}{*}{139} & \multirow[b]{2}{*}{-4.38} & \multirow[b]{2}{*}{0.001} \\
\hline Kredi Kullanan İşletmeler & 56 & 6.66 & 5.87 & & & \\
\hline
\end{tabular}

Süt sığırcılığı ile ilgili olarak Türkiye'nin doğu bölgesinde yer alan Elazığ ilinde 50 süt sığırı işletmesinde yürütülen bir araştırmada finansman kaynağına göre işletmeler iki grupta incelenmiştir. Birinci grupta yer alan işletmeler öz sermayelerinin yanı sıra kurumsal kaynaklardan da kredi kullanan işletmelerden oluşmuştur. İkinci gruptaki işletmeler ise kredi kullanmayan işletmelerden oluşmuştur. Katılımcıların \%74'ü hayvancılıktan elde ettikleri gelirle sermaye birikimi yapamadıklarını ve \%96'sı zamanında ödeyemedikleri borçlarını hayvanlarını satarak/kestirerek ödediklerini bildirmişlerdir. Araştırmada; sermayenin finansmanında işletmelerin \%44'ünün öz sermayelerinin yanı sıra kredi kullandığı, kredi kullananların kullanmayanlara göre büyükbaş hayvan varlığı $(p=0.042)$ ve yıllık süt üretimi $(p=0.047)$ ortalamaları aralarında istatistiki yönden farklılığın olduğu belirlenmiştir. Çalışma kapsamında incelenen işletmelerde sermayenin finansmanı; I. grupta \%44 $(n=22)^{\prime}$ ünde öz sermayelerinin yanı sıra banka kredilerinden, II. grupta \%56'sının $(n=28)$ ise sadece öz sermayeden yararlanarak kredi kullanmadıkları tespit edilmiştir.

Aynı araştırmada incelenen işletmelerin kredi taleplerini öncelikli olarak T.C. Ziraat Bankası, Tarım Kredi Kooperatifleri ve özel sektöre ait bankalar aracılığıyla karşıladıklarını ortaya koymuştur. İşletmelerde hayvan sayısı ve süt üretimi artışıyla birlikte sermaye gereksinimi de artmaktadır. Yapılan araştırmada; Süt sığırcılığı işletmelerinin düşük kâr marjı ile çalışması, işletmelerde sermaye birikiminin yetersizliği ve zamanı geçen borçların ödenmesinde hayvanların 
satılması/kesilmesi işletmelerin üretim araçlarını kaybetmelerine neden olduğu sonucuna varılmıştır (Arıkan ve Gökhan, 2019).

Türkiye'nin batısında yer alan İzmir ili Ödemiş ilçesinde süt sığırcılığı yapan 83 işletmede yürütülen bir çalışmada kredi kullanım oranının \%38.5 olduğu hesaplanmıştır (Koyubenbe, 2005). Ankara ilinde süt sığırcılığının yapısal sorunlarının incelendiği bir çalışmada ise kredi kullanma oranı \%40.3 olduğu bildirilmiştir (Tatar, 2007). Ege (Aydın ve Denizli) ve Orta Anadolu Bölgesindeki (Niğde ve Konya) illerde faaliyet gösteren 192 süt sığırcılık işletmesinde yürütülen bir çalışmada, işletmelerin \%47.3'ünün kredi kullandığı ve işletme ölçekleri arttıkça kredi kullanımının da arttığı bildirilmiştir (Murat, 2011).

Yapılan çalışmada süt sığırcılığı işletmelerinde oluşan toplam borcun \%60.23'ünün bankalardan alınan kredilerden oluştuğu tespit edilmiştir. Bununla birlikte süt sığırcılığı işletmelerinin \%41.43'ü (56 işletme) bankalardan tarımsal kredi kullanmıştır. Bu oran diğer araştırma bulgularıyla ( Koyubenbe, 2005; Tatar, 2007; Murat, 2011; Arıkan ve Gökhan, 2019) büyük oranda örtüşmektedir. Ayrıca işletme başına sağmal inek sayısı arttıkça tarımsal kredi talebinde bulunan işletmelerin sayısında da önemli düzeyde artış görülmekte olup tespit edilen bu sonuç Arıkan ve Gökhan (2019) tarafından tespit edilen aynı bulguyla tam olarak örtüşmektedir.

\section{Yağlık ayçiçeği üretim faaliyeti}

Türkiye'nin Trakya kesimini kapsayan araştırma 25 ilçede, 53 yerleşim biriminde bulunan 571 tarım işletmesinde yürütülmüştür. Araştırma alanında incelenen işletmelerde yağlık ayçiçeği ürünü bitkisel üretim deseninde $\% 42.73$, işletmelerin bitkisel üretim değerinde ise \%19.72 oranında pay almıştır. Yağlık ayçiçeği üreticilerinin \%28.60'ı tarımsal üretim için banka kredisi kullandıklarını ifade etmişlerdir. Tarımsal üretim için 159 işletme 2,573,260 TL banka kredi almıştır. Alınan kredinin işletme başına ortalaması 16,184.03 TL'dir (Çizelge 5).

Çizelge 5. Yağlık Ayçiçeği Üreten işletmelerin tarımsal üretim için kredi kullanım durumu

\begin{tabular}{|c|c|c|c|c|c|c|}
\hline \multirow{2}{*}{$\begin{array}{c}\text { İşletme } \\
\text { Büyüklük } \\
\text { Grupları (da) }\end{array}$} & \multicolumn{3}{|c|}{ Kredi Kullanım Durumu } & \multirow{2}{*}{$\begin{array}{c}\text { Kredi } \\
\text { Kullanım } \\
\text { Oranı (\%) }\end{array}$} & \multirow{2}{*}{ Kredi Miktarı } & \multirow{2}{*}{$\begin{array}{l}\text { İşletme Başına Kredi } \\
\text { Kullanım Miktarı (TL) }\end{array}$} \\
\hline & Evet & Hayır & Toplam & & & \\
\hline$\leq 20$ & 7 & 39 & 46 & 15.22 & 73000 & 10428.57 \\
\hline$\leq 40$ & 27 & 81 & 108 & 25.00 & 377000 & 13962.96 \\
\hline$\leq 60$ & 25 & 80 & 105 & 23.81 & 196100 & 7844.00 \\
\hline$\leq 100$ & 34 & 82 & 116 & 29.31 & 414760 & 12198.82 \\
\hline$\leq 150$ & 32 & 56 & 88 & 36.36 & 480400 & 15012.50 \\
\hline$<150$ & 34 & 59 & 93 & 36.56 & 1032000 & 30352.94 \\
\hline Toplam & 159 & 397 & 556 & 28.60 & 2573260 & 16184.03 \\
\hline
\end{tabular}

Anket uygulanan işletmelerin \%20.06'sı yağlık ayçiçeği üretimi için banka kredisi kullandıklarını beyan etmişlerdir. Yağıı ayçiçeği üretimi için 94 işletme toplam 1,176,350 TL banka kredisi almıştır. Alınan kredinin işletme başına ortalama değeri 12,514.36 TL'dir (Çizelge 6).

Çizelge 6. İşletmelerin yağlık ayçiçeği üretiminde tarımsal kredi kullanım durumu

\begin{tabular}{|c|c|c|c|c|c|c|}
\hline \multirow{2}{*}{$\begin{array}{c}\text { İşletme } \\
\text { Büyüklük } \\
\text { Grupları (da) }\end{array}$} & \multicolumn{3}{|c|}{ Kredi Kullanım Durumu } & \multirow{2}{*}{$\begin{array}{l}\text { Kredi Kullanım } \\
\text { Oranı (\%) }\end{array}$} & \multirow{2}{*}{$\begin{array}{l}\text { Kredi Miktarı } \\
\text { (TL) }\end{array}$} & \multirow{2}{*}{$\begin{array}{l}\text { İşletme Başına Kredi } \\
\text { Kullanım Miktarı (TL) }\end{array}$} \\
\hline & Evet & Hayır & Toplam & & & \\
\hline$\leq 20$ & 7 & 36 & 43 & 12.20 & 53000 & 7571.43 \\
\hline$\leq 40$ & 17 & 84 & 101 & 16.83 & 94850 & 5579.41 \\
\hline$\leq 60$ & 10 & 78 & 88 & 11.36 & 120100 & 12010.00 \\
\hline$\leq 100$ & 10 & 83 & 93 & 10.75 & 54500 & 5450.00 \\
\hline$\leq 150$ & 19 & 51 & 70 & 27.14 & 199500 & 10500.00 \\
\hline$<150$ & 33 & 42 & 75 & 44.00 & 654400 & 19830.30 \\
\hline Toplam & 94 & 374 & 468 & 20.09 & 1176350 & 12514.36 \\
\hline
\end{tabular}


Hem işletme genelinde hem de yağlık ayçiçeği üretimi özelinde tarımsal kredi kullanan işletme sayılarının işletme büyüklüğü arttıkça yükselme eğiliminde olduğu anlaşılmaktadır. Araştırma alanında ortalama işletme büyüklüğü Türkiye ortalamasının 2 katı civarındadır. Diğer bir ifade ile Trakya genelinde tarımsal işletme başına düşen ortalama arazi miktarı 100 da'nın üzerindedir. Bu durum 100 da ve üzerinde yağlık ayçiçeği üreten işletmeler özelinde dikkate alındığında kredi kullanım düzeyinin 100-149 da ile 150 da ve üzeri işletmelerde ne derece yüksek olduğu Çizelge 7'den de anlaşılmaktadır. Zira bu işletme büyüklük gruplarında kredi kullanım oranı $\% 27.14$ ve $\% 44.00$ düzeyindedir.

Çizelge 7. İşletmeler içinde kredi kullanan işletmelerin durumu

\begin{tabular}{cccc}
$\begin{array}{c}\text { Isşletme Büyüklük } \\
\text { Grupları (da) }\end{array}$ & $\begin{array}{c}\text { (A) Kredi Kullanan İşletmelerin } \\
\text { Ayçiçeği Ekim Alanı (da) }\end{array}$ & $\begin{array}{c}\text { (B)işletme Grubunun Toplam } \\
\text { Ayçiçeği Ekim Alanı (da) }\end{array}$ & Payı (A/B*100) \\
\hline S20 & 93 & 549.50 & 16.92 \\
$\leq 40$ & 393 & 3096.00 & 12.69 \\
$\leq 60$ & 533 & 5225.00 & 10.20 \\
$\leq 100$ & 769 & 8497.00 & 9.05 \\
$\leq 150$ & 2103 & 10653.00 & 19.74 \\
$<150$ & 9939 & 27368.00 & 36.32 \\
Toplam & 13830 & 55388.50 & 24.97 \\
\hline
\end{tabular}

Yağlık ayçiçeği üretiminde tarımsal kredi kullanan işletmelerin ekim alanının toplama oranı incelendiğinde, özellikle işletme büyüklüğü 100 da'nın üzerinde olduğu 5. ve 6. tabakalarda sırası ile yaklaşık \%20 ve \%36 pay aldıklarını göstermektedir. Bu durum küçük işletmelerin sermaye ihtiyaçlarını öz kaynaklarıyla karşıladığını, işletme ölçeği büyüdükçe bu üretim dalında işletme dışı yabancı sermayeye ihtiyaç duyulduğunu açıkça ortaya koymaktadır. Yapılan çalışmada anket uygulaması aşamasında yağlık ayçiçeği üreten işletme

Çizelge 8. Yağlık ayçiçeği üreten işletmelerde kredi kullanım durumlarına göre üreticilerin eğitim seviyelerinin (yıl) karşılaştırılması (t-testi sonuçları)

\begin{tabular}{lcccccc}
\hline Kredi Kullanım Durumu & $\mathrm{N}$ & Mean $(\overline{\mathrm{x}})$ & Std.Dev. & $\mathrm{df}$ & t value & Sig. $(\mathrm{p})$ \\
\hline Kredi Kullanmayan Iş̧letmeler & 477 & 5.90 & 2.36 & \multirow{2}{*}{569} & \multirow{2}{*}{-3.46} & \multirow{2}{*}{0.001} \\
Kredi Kullanan İşletmeler & 94 & 6.86 & 2.97 & & & \\
\hline
\end{tabular}

Yağlı ayçiçeği üreten işletmelerde kredi kullanan işletmeler ile kredi kullanmayan işletmeler arasında ortalama yağlık ayçiçeği üretim alanı varlığı (da) bakımında \%1 düzeyinde farklılık olduğu anlaşılmaktadır. Çizelge $9^{\prime} \mathrm{da}$ verilen test sahiplerinin tarımsal kredi kullanım kaynaklarına ilişkin ayrıntılı bilgi vermekten kaçınmaları nedeniyle bu konuda gerekli bilgi temin edilememiştir. Yağlık ayçiçeği üreten işletmelerde kredi kullanım durumlarına göre üreticilerin eğitim gördüğü ortalama yıl sayısı değerleri \%1 düzeyinde farklılık göstermektedir. Çizelge 8 'de verilen test sonuçlarına göre kredi kullanan işletmelerde ortalama eğitim süresi (yaklaşık 7 yıl) kredi kullanmayan işletme sahiplerine göre (yaklaşık 6 yıl) daha yüksek düzeydedir.
Çizelge 9. Yağlı ayçiçeği üreten işletmelerde kredi kullanım durumlarına göre yağlık ayçiçeği üretim alanı (da) d değerlerinin karşılaştırılması (t-testi sonuçları)

\begin{tabular}{lllllll}
\hline Kredi Kullanım Durumu & $\mathrm{N}$ & Mean $(\overline{\mathrm{x}})$ & Std.Dev. & $\mathrm{df}$ & $\mathrm{t}$ value & Sig. (p) \\
\hline Kredi Kullanmayan İşletmeler & 477 & 88.36 & 138.25 & \multirow{2}{*}{569} & \multirow{2}{*}{-3.35} & \multirow{2}{*}{0.001} \\
Kredi Kullanan İşletmeler & 94 & 140.85 & 143.43 & & & \\
\hline
\end{tabular}

\section{Pamuk üretim faaliyeti}

Araştırma verileri 2016/17 üretim döneminde Tabakalı Örnekleme Yöntemine göre 136 tarım işletmesinden elde edilmiştir. Anket uygulanan işletmelerin toplam tarım alanı varlığı 38,410 da'dır. Pamuk üreten işletmelerde bitkisel sonuçlarına göre kredi kullanan işletmelerde ortalama yağlık ayçiçeği üretim alanı (yaklaşık 141 da) kredi kullanmayan işletmelere göre (yaklaşık 88 da) daha yüksek düzeydedir. üretim deseni incelendiğinde ilk üç sırayı; pamuk (\%38.20), buğday (\%28.67) ve dane mısır (\%8.17) üretimi almaktadır. Araştırma alanında pamuk üreten işletmelerde tarımsal kredi kullanımına ilişkin veriler Çizelge 10'da verilmiştir. 
Çizelge 10. Pamuk üreten işletmelerde tarımsal kredi kullanımının işletme büyüklüğüne göre yansıması

\begin{tabular}{cccc}
$\begin{array}{c}\text { Işletme Büyüklük } \\
\text { Grupları }\end{array}$ & $\begin{array}{c}(\mathrm{A}) \\
\text { KrediKullanan Işletmelerin Pamuk } \\
\text { Ekim Alanı (da) }\end{array}$ & $\begin{array}{c}(\mathrm{B}) \\
\text { Iş̧letme Grubunun Toplam } \\
\text { Pamuk Ekim Alanı (da) }\end{array}$ & $\begin{array}{c}\text { Payı } \\
\left(\mathrm{A} / \mathrm{B}^{*} 100\right)\end{array}$ \\
\hline$\leq 100 \mathrm{da}$ & 2210 & 3419 & 64.64 \\
$>100 \mathrm{da}$ & 7745 & 11255 & 68.81 \\
Toplam & 9955 & 14674 & 67.84 \\
\hline
\end{tabular}

Incelenen işletmelerde tarımsal kredi kullanan işletmelerin sahip olduğu pamuk üretim alanının toplama oranı \%67.84 düzeyindedir. İşletmelerin pamuk üretim alanı arttıkça daha fazla sermayeye diğer bir ifade ile tarımsal krediye intiyaç duydukları anlaşılmaktadır. İncelenen işletmeler içinde pamuk üretiminde girdi tedariki için kredi kullanan işletmelerin toplam işletmeler içindeki payı \%63.97'dir. İşletmeler pamuk üretimi için 2,766,800 TL kredi kullanmış olup, işletme başına ortalama kredi kullanım tutarı 31,802.30 TL'dir. Diğer bir bakış açısına göre pamuk üretim alanlarında birim alana kredi kullanım miktarı $277.93 \mathrm{TL} / \mathrm{da}$ olarak hesaplanmıştır (Çizelge 11).

Çizelge 11. İncelenen işletmelerde pamuk üreticilerinin kredi kullanım durumu

\begin{tabular}{|c|c|c|c|c|}
\hline \multirow{2}{*}{$\begin{array}{c}\text { Kredi } \\
\text { Kaynakları }\end{array}$} & \multirow{2}{*}{ Kriterler } & \multicolumn{2}{|c|}{$\begin{array}{c}\text { İşletme Büyüklük } \\
\text { Grupları }\end{array}$} & \multirow[t]{2}{*}{ Toplam } \\
\hline & & $\leq 100 \mathrm{da}$ & $>100 \mathrm{da}$ & \\
\hline \multirow[t]{3}{*}{ Banka } & Kredi Kullanan İşletme Sayısı & 33 & 48 & 81 \\
\hline & Kullanılan Kredi Miktarı (TL) & 543800 & 2111500 & 2655300 \\
\hline & İşletme Başına Ortalama Kredi Kullanımı (TL) & 16454.55 & 43989.58 & 3281.48 \\
\hline \multirow[t]{3}{*}{ TKK } & Kredi Kullanan İşletme Sayısı & 1 & 1 & 2 \\
\hline & Kullanılan Kredi Miktarı (TL) & 7000 & 30000 & 37000 \\
\hline & İşletme Başına Ortalama Kredi Kullanımı (TL) & 7000 & 30000 & 18500 \\
\hline \multirow[t]{3}{*}{ Şahıs+Tüccar } & Kredi Kullanan İşletme Sayısı & 4 & 0 & 4 \\
\hline & Kullanılan Kredi Miktarı (TL) & 74500 & 0 & 74500 \\
\hline & İşletme Başına Ortalama Kredi Kullanımı (TL) & 18625 & 0 & 18625 \\
\hline \multirow[t]{3}{*}{ Toplam } & Kredi Kullanan İşletme Sayısı & 38 & 49 & 87 \\
\hline & Kullanılan Kredi Miktarı (TL) & 625300 & 2141500 & 2766800 \\
\hline & İşletme Başına Ortalama Kredi Kullanımı (TL) & 16455.26 & 43704.08 & 31802.30 \\
\hline
\end{tabular}

İncelenen işletmelerin yaklaşık \%94'ü pamuk üretiminde tarımsal üretime kredi veren bankalardan kredi kullanmışlardır. Bankalar tarafından kullandırılan kredilerin toplam kredi içindeki payı ise \%96 düzeyindedir. Tarım Kredi kooperatifi ile şahıs ve tüccarlardan alınan kredi miktarı ve üretici sayısı toplam içinde oldukça düşük bir değere sahip olduğu anlaşılmaktadır. Tarımsal kredi kullanım kaynakları içinde Ziraat Bankası'nı tercih eden işletmelerin oranı \%93.83 olarak tespit edilmiştir.
Pamuk üretiminde kredi kullanan işletmelerle kredi kullanmayan işletmeler arasında birim alandan elde edilen verim değerleri bakımından \%10 düzeyinde farklılık olduğu anlaşılmaktadır. Çizelge 12 'de verilen test sonuçlarına göre kredi kullanan işletmelerde pamuk üretiminde birim alandan elde edilen verim değeri (yaklaşı $548 \mathrm{~kg} / \mathrm{da}$ ) kredi kullanmayan işletmelere göre (yaklaşık 519 kg/da) daha yüksek düzeydedir.

Çizelge 12. Pamuk üreten işletmelerde kredi kullanım durumlarına göre birim alana verim (kg/da) değerlerinin $\mathrm{k}$ karşılaştırılması (t-testi sonuçları)

\begin{tabular}{lcccccc}
\hline \multicolumn{1}{c}{ Kredi Kullanım Durumu } & $\mathrm{N}$ & Mean $(\overline{\mathrm{x}})$ & Std.Dev. & $\mathrm{df}$ & $\mathrm{t}$ value & Sig. $(\mathrm{p})$ \\
\hline Kredi Kullanmayan İşletmeler & 55 & 519.38 & 106.57 & & & \\
Kredi Kullanan İşletmeler & 81 & 547.60 & 94.07 & 134 & -1.63 & 0.096 \\
\hline
\end{tabular}

Pamuk üretiminde kredi kullanan işletmeler ile kullanmayan işletmeler arasında işletme başına ortalama pamuk üretim alanı (da) bakımından istatistiki yönden \%1 düzeyinde farklılık olduğu 
görülmektedir. Çizelge 13'teki test sonuçlarına göre kredi kullanan işletmelerde ortalama pamuk üretim alanı (yaklaşık 116 da) kredi kullanmayan işletmelere göre (yaklaşık $95 \mathrm{da}$ ) daha yüksek düzeydedir.

Çizelge 13. Pamuk üreten işletmelerde kredi kullanım durumlarına göre pamuk üretim alanı (da) değerlerinin karşılaştırılması (t-testi sonuçları)

\begin{tabular}{lllllll}
\hline Kredi Kullanım Durumu & $\mathrm{N}$ & Mean $(\overline{\mathrm{x}})$ & Std.Dev. & $\mathrm{df}$ & t value & Sig. $(\mathrm{p})$ \\
\hline Kredi Kullanmayan İşletmeler & 55 & 95.31 & 59.79 & \multirow{2}{*}{134} & \multirow{2}{*}{-1.97} & \multirow{2}{*}{0.048} \\
Kredi Kullanan İşletmeler & 81 & 116.44 & 62.63 & & \\
\hline
\end{tabular}

\section{Kanola üretim faaliyeti}

Araştırmada kullanılan veriler Çanakkale ilinde kanola üreten ve tam sayım yöntemine göre belirlenen 83 tarım işletmesinden elde edilmiştir. Incelenen işletmelerin toplam tarımsal üretimde kullandıkları alan 22,447 da olup; bitkisel üretim deseninde ilk sırayı \%31.09 ile kanola üretimi almaktadır. Bu ürünü sırasıyla buğday (\%30.73), çeltik (\%10.37), yağlık ayçiçeği (\%10.03) ve arpa üretimi (\%6.60) izlemektedir. İncelenen işletmelerde toplam 6,978 da alanda 2,066,878 kg kanola üretimi gerçekleştirilmiş olup, işletme başına ortalama kanola üretim alanı $84.07 \mathrm{da}$, verim değeri ise $296.20 \mathrm{~kg} / \mathrm{da}$ olarak hesaplanmıştır. Araştırma kapsamındaki işletmelerde kanola üretiminde kredi kullanım durumuna ait bilgiler Çizelge 14'te verilmiştir.

Çizelge 14. Kanola üreten işletmeler işletme büyüklüklerine göre kredi kullanım durumu

\begin{tabular}{|c|c|c|c|c|c|c|}
\hline \multirow[b]{2}{*}{$\begin{array}{l}\text { İşletme } \\
\text { Büyüklük } \\
\text { Grupları }\end{array}$} & \multicolumn{2}{|c|}{ Kredi Kullanım Durumu } & \multirow[t]{2}{*}{$\underline{\text { Toplam }}$} & \multicolumn{3}{|c|}{ Kredi Kullanan İşletmelerin } \\
\hline & $\begin{array}{c}\text { Kullanan } \\
\text { İşletme Say. }\end{array}$ & $\begin{array}{l}\text { Kullanmayan } \\
\text { İşletme Say. }\end{array}$ & & $\begin{array}{c}\text { (A) } \\
\text { Kanola Üretim } \\
\text { Alanı (da) }\end{array}$ & $\begin{array}{c}\text { (B) } \\
\text { Toplam Kanola } \\
\text { Üretim Alanı (da) }\end{array}$ & $\begin{array}{c}\text { Payı } \\
\text { (A/B) (\%) }\end{array}$ \\
\hline$\leq 40 \mathrm{da}$ & 8 & 36 & 44 & 214 & 975 & 21.95 \\
\hline$<40 \mathrm{da}$ & 14 & 25 & 39 & 3138 & 6003 & 52.27 \\
\hline Toplam & 22 & 61 & 83 & 3352 & 6978 & 48.04 \\
\hline
\end{tabular}

Türkiye'de tarım işletmelerinin küçük ölçekli olması gelirin düşük olması yanında bir sonraki üretim dönemi için ihtiyaç duyulan sermayenin teminini de güçleştirmektedir. Yapılan çalışmada incelenen işletmelerin yaklaşık \%27'sinin kanola üretimi için gerekli sermayenin bir bölümünü dış kaynaklardan temin ettiğini ortaya koymuştur. Kanola üreten işletmelerde, öz sermaye yetersizliği nedeniyle, işletme büyüklüğü arttıkça dış sermaye talebinin de artış gösterdiği anlaşılmaktadır. Zira 40 da ve altında kanola üreten işletmelerde kredi kullanan işletmelerin grup içindeki payı \%18.18 ve bu işletmelerin grup içindeki toplam kanola üretim alanlarındaki payı \%21.95 düzeyinde iken, $40 \mathrm{da}$ üzeri işletmelerde belirtilen değerler sırasıyla
\%35.90 ve \%52.27 olarak gerçekleşmiştir (Çizelge 14).

Yapılan çalışmada anket uygulaması aşamasında kanola üreten işletme sahiplerinin tarımsal kredi kullanım kaynakları konusunda ayrıntılı bilgi vermekten kaçınmaları nedeniyle bu konuda gerekli bilgi temin edilememiştir.

Kanola üretiminde tarımsal kredi kullanan işletmeler ile kredi kullanmayan işletmeler arasında birim alandan elde edilen ortalama verim değeri bakımından istatistiki yönden \%7 düzeyinde farklılık göstermektedir. Çizelge $15^{\prime}$ te verilen test sonuçlarına göre kredi kullanan işletmelerde birim alandan elde edilen ortalama kanola verim değeri (308 kg/da) kredi kullanmayan işletmelere göre (285 kg/da) daha yüksek düzeydedir.

Çizelge 15. Kanola üreten işletmelerde kredi kullanım durumlarına göre birim alana verim $(\mathrm{kg} / \mathrm{da})$ değerlerinin karşılaştırılması (t-testi sonuçları)

\begin{tabular}{lcccccc}
\hline Kredi Kullanım Durumu & $\mathrm{N}$ & Mean $(\overline{\mathrm{x}})$ & Std.Dev. & df & t value & Sig. (p) \\
\hline Kredi Kullanmayan Iş̧letmeler & 61 & 284.64 & 57.20 & & & \\
Kredi Kullanan İşletmeler & 22 & 308.14 & 48.82 & & -1.71 & 0.07 \\
\hline
\end{tabular}

Kanola üretiminde tarımsal kredi kullanan işletmeler ile kredi kullanmayan işletmeler arasında ortalama kanola üretim alanı (da) bakımından istatistiki yönden \%1 düzeyinde farklılık olduğu 
tespit edilmiştir. Çizelge $16^{\prime}$ da verilen test sonuçlarına göre kredi kullanan işletmelerde ortalama kanola üretim alanı (182 da) kredi kullanmayan işletmelere göre (49 da) daha yüksek düzeydedir.

Çizelge 16. Kanola üreten işletmelerde kredi kullanım durumlarına göre kanola üretim alanı (da) değerlerinin karşılaştırılması (t-testi sonuçları)

\begin{tabular}{lcccccc}
\hline Kredi Kullanım Durumu & $\mathrm{N}$ & Mean $(\overline{\mathrm{x}})$ & Std.Dev. & $\mathrm{df}$ & $\mathrm{t}$ value & Sig. $(\mathrm{p})$ \\
\hline Kredi Kullanmayan İşletmeler & 61 & 48.65 & 46.65 & \multirow{2}{*}{81} & \multirow{2}{*}{-3.85} & \multirow{2}{*}{0.001} \\
Kredi Kullanan İşletmeler & 22 & 182.27 & 262.19 & & & \\
\hline
\end{tabular}

\section{Çeltik üretim faaliyeti}

Araştırma kapsamında Tabakalı Örnekleme Yöntemine göre belirlenen 74 işletmeden elde edilen veriler kullanılmıştır. Araştırma sonuçlarına göre incelenen işletmelerde; çeltik üretim alanları bitkisel üretim deseninde $\% 44^{\prime}$ lük pay ile ilk sırada yer almakta olup, ortalama çeltik üretim alanı $141.36 \mathrm{da}$, ortalama verim değeri ise $785.18 \mathrm{~kg} / \mathrm{da}$ olarak hesaplanmıştır.
Türkiye'de tarım işletmelerinin küçük ölçekli olması gelirin düşük olması yanında bir sonraki üretim dönemi için ihtiyaç duyulan sermayenin teminini de güçleştirmektedir. Yapılan çalışma, incelenen işletmelerin yaklaşık \%51'inin çeltik üretimi için gerekli sermayenin bir bölümünü dış kaynaklardan temin ettiğini ortaya koymuştur (Çizelge 17). Bu durum çeltik üreten işletmelerin yarıya yakın kısmının yeterli sermaye birikimine sahip olmadığı ortaya koymaktadır.

Çizelge 17. Çeltik üretiminde işletme büyüklüklerine göre kredi kullanım durumu

\begin{tabular}{lccccccc}
\hline & \multicolumn{7}{c}{ Tabakalar } \\
\cline { 2 - 7 } & 1 & 2 & 3 & 4 & 5 & Toplam & Payı (\%) \\
\hline Kredi Kullanan İşı. Say. (A) & 3 & 3 & 9 & 10 & 13 & 38 & 51.35 \\
Kredi Kullanmayan İşı.Say. (B) & 6 & 6 & 8 & 10 & 6 & 36 & 48.65 \\
Toplam İşl. Sayısı & 9 & 9 & 17 & 20 & 19 & 74 & 100.00 \\
Payı (A/B) (\%) & 33.33 & 33.33 & 52.94 & 50.00 & 68.42 & 51.35 & - \\
\hline
\end{tabular}

Çizelge 17 incelendiğinde işletme büyüklüğünün arttıkça işletmelerde kullanılan dış kaynaklı kredi kullanım oranının da artış gösterdiği ortaya çıkmaktadır. Diğer bir ifade ile 1. ve 2.grupta yer alan işletmelerin öz sermaye kullanarak çeltik üretiminde bulunduğunu, 3. ve 4. Grupta yer alan işletmelerde işletme dışından sermaye temininin yaklaşık \%50 düzeyinde olduğunu, en yüksek işletme grubunda ise bu oranın \%68'e yükseldiği görülmektedir. Çeltik üreten işletmelerde işletme büyüklüklerine göre kredi kullanılarak üretim yapılan alanın toplam çeltik üretim alanındaki payına ilişkin bilgiler Çizelge $18^{\prime}$ de verilmiştir.

Çizelge 18. Çeltik üreten işletmelerde işletme büyüklüklerine göre kredi kullanımı

\begin{tabular}{cccc}
$\begin{array}{c}\text { I̧şletme Büyüklük Grupları } \\
\text { (da) }\end{array}$ & $\begin{array}{c}\text { (A) Kredi Kullanan Iş̧letmelerin } \\
\text { Çeltik Üretim Alanı (da) }\end{array}$ & $\begin{array}{c}\text { (B) Toplam Çeltik Üretim } \\
\text { Alanı (da) }\end{array}$ & Payı (A/B) (\%) \\
$\leq 25$ & 45 & 149 & 30.20 \\
$\leq 50$ & 98 & 325 & 30.15 \\
$\leq 100$ & 641 & 1189 & 53.91 \\
$\leq 200$ & 1415 & 2911 & 48.61 \\
$>200$ & 3958 & 5887 & 67.23 \\
Toplam & 6157 & 10461 & 58.86 \\
\hline
\end{tabular}

Yapılan çalışmada anket uygulaması aşamasında çeltik üreten işletme sahiplerinin tarımsal kredi kullanım kaynakları konusunda ayrıntılı bilgi vermekten kaçınmaları nedeniyle bu konuda gerekli bilgi temin edilememiştir. Çeltik üretiminde kredi kullanan işletmeler ile kredi kullanmayan işletmeler arasında işletme sahiplerinin eğitim gördüğü ortalama yıl sayısı bakımında istatistiki yönden \%2 düzeyinde farklılık olduğu saptanmıştır. Çizelge 19'deki test sonuçlarına göre kredi kullanan işletmelerde ortalama eğitim süresi (yaklaşık 9 yıl) kredi 
kullanmayan işletme sahiplerine göre (yaklaşık 7 yıl) daha yüksek düzeydedir.

Çizelge 19. Çeltik üreten işletmelerde kredi kullanım durumlarına göre üreticilerin eğitim seviyelerinin (yıl) karşılaştırılması (t-testi sonuçları)

\begin{tabular}{lcccccc}
\hline Kredi Kullanım Durumu & $\mathrm{N}$ & Mean $(\overline{\mathrm{x}})$ & Std.Dev. & df & t value & Sig. $(\mathrm{p})$ \\
\hline Kredi Kullanmayan İşletmeler & 36 & 7.33 & 2.69 & 72 & -2.53 & 0.013 \\
Kredi Kullanan Iş̧letmeler & 38 & 9.15 & 3.44 & & & \\
\hline
\end{tabular}

Dünya genelinde bitkisel üretimde tarımsal kredi kullanımı konusunda yapılan önemli sayıda araştırma bulunmaktadır. Tarımsal kredi kullanımı konusunda Erzurum ilinde yapılan bir araştırmada tabakalı örnekleme metodu kullanılarak belirlenen çiftçilerin (914 işletme) \%63'ünün (577 işletme) hiç kredi kullanmadığı ve \%14'ünün (131 işletme) ise her yıl kredi aldıkları belirlenmiştir. Çalışmada üreticilerin kullanmış oldukları kredi kaynakları ise; TCZB \%53.2, Tarım Kredi Kooperatifi \%44.8, diğer \%1.9 olarak belirlenmiştir (Kara ve Kadıŏlu, 2004).

Altürk (2007) tarafından Ankara ili Polatlı ilçesinde "Tabakalı Tesadüfî Örnekleme Yöntemi" ne göre belirlenen 75 üreticiyle yapılan çalışmada; araştırma alanında, işletme genişlikleri büyüdükçe birim dekara masrafların ve buna bağlı olarak da kredi gereksiniminin azaldığı, Tarım Kredi kooperatiflerinin verdiği kredilerin çiftçilerin o döneme ait masraflarını karşılamakta yetersiz kaldığı sonucuna ulaşılmıştır. Çalışma kapsamında incelenen işletmelerde üreticilerin büyük çoğunluğunun teşkilatlanmamış kredi kaynaklarına başvurduğu tespit edilmiştir.

Ankara ilinde yürütülen bir araştırmada tabakalı tesadüfi örnekleme yöntemi ile seçilen 139 tarım işletmesinden anket yoluyla toplanan verilerden elde edilen sonuçlara göre, işletmeler ortalamasında 2009-2013 yılları arasında \%32.41 oranında sübvansiyonlu kredi kullanıldığı tespit edilmiştir. Sübvansiyonlu kredi kullanım oranı 1. grup işletmelerde \%25.91 iken, 2. Grupta \%31.98 ve 3. grupta $\% 40.49$ olarak belirlenmiştir. Araştırma bölgesinde işletmecilerin \% 51.8 gibi çok büyük bir kısmının TCZB'nı tercih ettiği görülmüştür (Tosun ve Güneş, 2017).

Konu ile ilgili olarak Niğde ve Karaman illerinde Oransal Örnekleme tekniği ile belirlenen 67 çiftçi ile yapılan araştırmada çiftçiler arasında tarımsal kredi kullanım düzeyini \%76.7 olarak tespit edilmiş olup, 2017 yılında bölgede işletme başına düşen ortalama tarımsal kredi kullanım miktarı 79,967 TL olarak hesaplanmıştır (Berk ve Armağan, 2019).

Yapılan çalışmada Tokat İ merkezine bağlı 6 köyde 86 adet tarım işletmesi ile yüz yüze anket yapılmıştır. Anketlerden elde edilen bulgulara göre, işletmelerin \%48'i ziraat bankası, \%32'si kredi kooperatifi, \%18.4'ü özel bankalar, \%1.6'sı satış kooperatifinden kredi temin ettiği belirlenmiştir (Erdal ve Erdal, 2019). Bangladeş'te 60 üreticiyi kapsayan bir araştırmada üreticilerin \%34'ünün (21 işletme) tarımsal üretim faaliyetlerini sürdürebilmeleri için tarımsal kredi kullandıkları sonucuna varılmıştır (Mitra and Prodhan, 2018). Ukrayna'da 250 tarım işletmesi üzerinde yapılan bir araştırmada üreticilerin \%21.20'si (53 işletme) tarımsal üretimde bulunmak için bankalar kanalıyla tarımsal kredi kullandıklarını beyan etmişlerdir (Tetyana et al., 2020).

Yapılan araştırmada; çeltik üreten işletmelerin \%51.35'i tarımsal kredi kullanmıştır. Bu oran diğer faaliyetler için; kanolada \%26.51, pamukta \%59.56 ve yağlık ayçiçeğinde \%16.46 düzeyindedir. Üretim faaliyetinde kredi kullanılarak üretim yapılan alanın toplam alana oranı çeltikte \%58.56, kanolada \%48.04, pamukta \%59.56 ve yağlık ayçiçeğinde ise \%24.97 düzeyindedir. Bununla birlikte yapılan araştırma işletme büyüklükleri arttıkça kredi talep eden işletmelerin sayısında da önemli derecede artış olduğunu ortaya koymaktadır. Yapılan değerlendirmede özellikle tarımsal faaliyette bulunan işletmeler içinde tarımsal kredi kullanım oranlarının diğer araştırma bulguları ile karşılaştırıldığında önemli oranda benzerlik gösterdiği anlaşılmaktadır (Kara ve Kadıoğlu, 2004; Tosun ve Güneş, 2017; Mitra and Prodhan, 2018; Berk ve Armağan, 2019; Erdal ve Erdal, 2019; Tetyana et al., 2020). Yapılan araştırma tarımsal kredi kullanan işletmelerde süt verim değeri ile kanola ve pamukta birim alandan elde edilen verim değerlerinin kredi kullanmayan işletmelere göre istatistiki açıdan önemli derecede fark olduğunu göstermiştir. Diğer bir ifade ile tarımsal kredi kullanan işletmelerde birim alandan elde edilen verim değerleri diğer işletmelere göre daha yüksektir. Benzer şekilde Pakistan'da yapılan araştırmalarda tarımsal kredi kullanımının buğday ve çeltik üreten işletmelerde birim alandan elde edilen verim düzeyini istatistiki açıdan artırdığını ortaya koymaktadır (Bashir and Mehmood, 2010; Chandio et al., 2018). 
Çalışmada tarımsal kredi kullanımında ilk sırada Ziraat Bankasının olduğu görülmektedir. Bu sonuç diğer araştırma bulgularıyla örtüşmektedir (Kara ve Kadıoğlu, 2004; Tosun ve Güneş, 2017; Erdal ve Erdal, 2019). İnan (2016) tarafından hazırlanan yayında Türkiye'de tarımsal kredi kullanımında üreticiler tarafından ilk sırada tercih edilen ve parasal büyüklük olarak da ülke genelinde ilk sırayı alan kuruluşun Ziraat Bankası olduğu belirtilmektedir.

\section{Sonuç ve Öneriler}

Türkiye'deki tarım işletmelerinin önemli bir kısmının küçük ölçekli olması bu işletmelerde yaşayan insanların ekonomik, sosyal ve kültürel ihtiyaçlarını karşılamaktan uzak olmakla birlikte, bir sonraki üretim dönemi için gerekli olan sermayenin sağlanmasını da güçleştirmektedir. Zira tarım işletmeleri; küçük aile işletmeciliğinde tasarrufun zorluğu, sermayenin yavaş devri, risk ve belirsizlerin çokluğu, teknolojik değişmeler ve değişen pazar istekleri, tarımsal ürün fiyatlarındaki dalgalanmalar nedeniyle dış sermayeye sürekli ihtiyaç duymaktadır. Tarımsal üretimde bulunan işletmeler; sınırlı tasarruf olanakları nedeniyle talep ettiği öz sermayedeki noksanlık kredi edinmek suretiyle özel ve resmi kurum ve kuruluşlar tarafından finanse edilmektedir. Yapılan araştırmada Türkiye'de süt sığırcılığı, çeltik, kanola, pamuk ve yağlık ayçiçeği üreten işletmelerin tarımsal kredi kullanım durumu ayrıntılı olarak incelenmiştir.

Araştırma sonuçları çeltik üreticilerinin \%51'inin üretim alanının \%59'unu oluşturan alanda, kanola üreticilerinin $\% 27$ 'sinin üretim alanının $\% 48$ 'inde, pamuk üreticilerinin $\% 60$ 'ının üretim alanlarının \%67'sinde, yağlık ayçiçeği üreticilerinin $\% 16$ sının üretim alanlarının $\% 25^{\prime}$ inde üretimde bulunabilmek için tarımsal kredi kullandıklarını ortaya koymuştur. Çalışma süt sığırcılığı faaliyetinde bulunan işletmelerin \%41'inin banka kaynaklı tarımsal kredi kullandıklarını ve toplam işletme borçları içinde tarımsal kredilerin \%60 düzeyinde pay aldığı göstermiştir.

Yapılan araştırma tarımsal kredi kullanan işletmelerin kullanmayan işletmelere göre; süt sığırcılığı işletmelerinde sağmal inek başına süt verim değerlerinin \%1 düzeyinde, sağmal inek varlığının ise \%1 düzeyinde istatistiki açıdan farklılık gösterdiğini ortaya koymuştur. Benzer durum yağlık ayçiçeği üreten işletmelerde üreticilerin eğitim gördüğü ortalama yıl sayısı değerlerinin \%1 düzeyinde, yağlık ayçiçeği üretim alanı varlığında (da) \%1 düzeyinde, pamuk üreten işletmelerde pamuk üretim alanı varlığının (da) \%1 düzeyinde, birim alandan elde edilen verim değerlerinin de \%10 düzeyinde farklılık göstermektedir. Aynı şekilde kanola üreten işletmelerde kanola üretim alanı varlığı (da) \%1 düzeyinde, birim alandan elde edilen verim değerleri \%7 düzeyinde farklılık gösterirken, çeltik üreten işletmelerde üreticilerin eğitim gördüğü ortalama yıl sayısı değerlerinin diğer işletmelere göre $\% 2$ düzeyinde istatistiki açıdan anlamlı bir farklılık olduğu anlaşılmaktadır.

Yürütülen araştırma; incelenen işletmelerde işletme büyüklüğü arttıkça süt sığırcılığı işletmelerinde sağmal inek sayısı ve süt verim değerindeki artışa paralel olarak tarımsal kredi kullanan işletmelerin sayısının ve işletme başına ortalama tarımsal kredi kullanım miktarının da artış gösterdiğini ortaya koymuştur.

Yapılan çalışma Türkiye'de tarım işletmelerinin, yapısal sorunlar nedeniyle, önemli düzeyde sermaye ihtiyacına gereksinim duyduğunu, bu ihtiyacın da işletmelerin büyüklükleri arttıkça şiddetlendiğini göstermektedir. Türkiye'de tarım sektörünün finansman ihtiyacını karşılamada en önemli kuruluş T.C.Ziraat Bankasıdır. Yapılan araştırmada tarımsal kredi kullanan işletmelerin kredi temininde ilk başvurdukları kurumun T.C.Ziraat Bankası olduğunu göstermiştir.

Türkiye'de son yıllarda tarımsal üretimde sürdürülebilirliğin sağlanması ve işletmelerin ayakta kalabilmeleri için halen devam etmekte olan tarımsal kredilerdeki "0 ya da düşük faizli kredi uygulaması"nın orta ve uzun vadede mutlaka devam etmesi gerekmektedir. Yürürlükteki uygulamanın devamlılığı ülke için önümüzdeki dönemlerde tarımsal üretimin daha uygun koşullarda yapılması için kuşkusuz iyi bir ortam hazırlayacaktır.

Teşekkür: Çalışma kapsamında yer alan; “Ayçiçeği Tarımında Verimlilik ve Destekleme Politikalarının Etkinliğinin Belirlenmesi (Proje No: Tagem 08/ARGE/6 )" isimli projeyi destekleyen Tarım ve Orman Bakanlığı'na, "Hatay ili Süt Sığırcılığının Ekonomik Analizi (Proje No:2013-9162)" ve "Hatay İli Tarım İşletmelerinde Pamuk Üretiminin Ekonomik Analizi" (Proje No:2017-16322) isimli projeleri destekleyen Hatay Mustafa Kemal Üniversitesi BAP Birimine, "Çanakkale illinde Çeltik Üretiminin Ekonomik Analizi (Proje No: FBA-2018-2605)" ve "Çanakkale İlinde Kanola Üretiminin Ekonomik Analizi (No: FHD2018-2664)" isimli projeleri destekleyen Çanakkale Onsekiz Mart Üniversitesi BAP Birimine teşekkür ederiz. Araştırma sırasında sorularımızı sabırla dinleyip, samimi ve içtenlikle cevaplayan; Edirne, Kırklareli, Tekirdağ, Çanakkale ve İstanbul ili yağlık ayçiçeği üreticilerine, Hatay ili süt sığırcılığı işletmelerine ve ildeki pamuk üreticilerine, Çanakkale ili çeltik ve kanola üreticilerine şükranlarımı sunarım. 
Çıkar Çatışması Beyanı: Makale yazarları aralarında herhangi bir çıkar çatışması olmadığını beyan ederler.

\section{Araştırmacıların Katkı Oranı Beyan Özeti:} Yazarlar makaleye eşit oranda katkı sağlamış olduklarını beyan ederler.

\section{Kaynaklar}

Altürk, D. 2007. Polatlı İlçesi Tarım işletmelerinde Münavebede Yer Alan Başlıca Ürünlerde işletme Sermayesi Talebi ve Kredi Kullanımının incelenmesi. Yüksek Lisans Tezi. Ankara Ün. Fen Bil. Enst. Tarım Ekonomisi Ana Bilim Dalı. Ankara. ss. 94.

Andriushchenko, K., Ishchenko, M., Sahaidak, M., Tepliuk, M., Domina, O. 2019. Prerequisites for the creation of financial and credit infrastructure of support for agricultural enterprises in Ukraine. Banks and Bank Systems, 14(2): 63-75. (doi:10.21511/bbs.14(2).2019.06)

Arıkan, M.S., Gökhan, E.E. 2019. Süt sığırcılığı işletmelerinde finansman kaynakları ve kredi kullanım durumlarının değerlendirilmesi: Elazığ ili örneği. Vet. Hekim. Der. 90 (1): 43-49.

Bashir, M.K., Mehmood, Y. 2010. Institutional credit and rice productivity: a case study of District Lahore, Pakistan. China Agricultural Economic Review. 2 (4): 412419. DOI 10.1108/17561371011097722

Berk, A., Armağan, S. 2019. Çiftçilerin Tarımsal Kredi Tercihleri Ve Sorunlarının Belirlenmesi Üzerine Bir Araştırma. $3^{\text {th }}$ International Conference on Food and Agricultural Economics. 25-26th April 2019, Alanya, Turkey. s.87-94.

Boldyreva, I., Tinyakova, V., Alpatova, Y., Zhusipova, E. 2020. financing mechanism for operating and investment activities in agriculture of Russia. Advances in Economics, Business and Management Research (Proceedings of the International Conference on Economics, Management and Technologies 2020 (ICEMT 2020),139: 34-39. (doi.org/10.2991/aebmr.k.200509.007).

Chandio, A.A., Jiang, Y., Wei, F., Guangshun, X. 2018. Effects of agricultural credit on wheat productivity of small farms in Sindh, Pakistan. Are short-term loans better?. Agricultural Finance Review 78 (5): 592610. DOI 10.1108/AFR-02-2017-0010

Çetin, B. 2014.Tarımsal Finansman. Nobel Akademik Yayıncılık Eğitim Danışmanlık Tic. Ltd. Şti.
Yayın No:941, iktisat Ekonomi No:170,Geliştirilmiş 2.Baskı.Ankara.

Çiçek, A., Erkan, O. 1996. Tarım Ekonomisinde Araştırma ve Örnekleme Yöntemleri. GOP Ün. Ziraat Fak. Yay. No:6, Tokat.

Doll, J.P., Orazem, F. 2005. Teorik ve Uygulamalı Üretim Ekonomisi. (Editör Şinasi Akdemir, Çeviren Tuna Alemdar).Seçkin Yayıncılık San. Ve Tic. A.Ş., Ekonomi Kitapları Dizisi:16, Ankara.

Duval, A.T. 2003. "AgricultureFinance and Credit Infrastructure-Conditions, Policies and Channels". Agric. Econ. - Czech, 49, 2003 (3): 106-112

Elias, S., Ahmad, I.M., Patil, B.L. 2015. The Determinants of Access to Agricultural Credit for Small and Marginal Farmers' In Dharwad District, Karnataka, India. Research Journal of Agriculture and Forestry Sciences, 3(5): 1-5.

Erdal, H., Erdal, G. 2019. Tokat Merkez İlçe Köylerinde Faaliyet Gösteren Tarımsal Işletmelerin Kredi Kullanım Durumlarının Belirlenmesi. $\quad 4^{\text {th }} \quad$ International Symposium on Innovative Approaches in Social, Human and Administrative Sciences. November 22-24, 2019, Samsun, Turkey. 4 (8), 75-79, 2019

Green, S.B., Salkind, N.J. , Akey, T.M. 2000. Using SPSS For Windows, Analyzing and Understanding Data. Second Edition. Prentice Hall Inc., Upper Saddle River. New Jersey, USA. 430 p.

Gujarati, D.N. 2009. Temel Ekonometri. Literatür Yayınları No:33, İstanbul. s.107.

Hananu, B., Abdul-Hanan, A., Zakaria, H. 2015. Factors influencing agricultural credit demand in Northern Ghana. African Journal of Agricultural Research, 10(7): $645-652$.

Ijioma, J.C., Osondu, C.K. 2015. Agricultural Credit Sourcesand Determinants of Credit Acquisition by Farmers in Idemili LocalGovernment Area of Anambra State". Journal of Agricultural Science and Technology B 5 (2015) 34-43 (doi: 10.17265/2161-6264/2015.01.004), David Publishing.

İnan, i..H. 2016. Tarım Ekonomisi ve İşletmeciliği. İdeal Kültür\&Yayıncılık. İstanbul. $415 \mathrm{~s}$.

Jouault, A., Featherstone, M.A. 2006. "DeterminingtheProbability of Default of AgriculturalLoans in a French Bank", 2006 Annual Meeting, July 23-26, LongBeach, CA 21376, American Agricultural Economics Association. 
Kara, A., Kadıŏ̆lu, S. 2004. Kuzey Doğu Anadolu Bölgesinde Çiftçilerin Kooperatifleşme Durumu, Tarımsal Kredi Kullanımı ve ilgili Problemler. Türkiye VI. Tarım Ekonomisi Kongresi, 16-18 Eylül 2004. Tokat. S.460465.

Katchova, A.L. 2005. Factors affecting farm credit use. Agricultural Finance Review,65(2): 17-29.

Koç, A.A., Yu, T.E., Kıymaz, T., Sharma, B.P. 2019. Effects of government supports and credits on Turkish agriculture: A spatial panel analysis, Journal of Agribusiness in Developing and Emerging Economies, 9 (4): $\quad 391-401$. (doi.org/10.1108/JADEE11-2018-0164)

Koyubenbe, N. 2005. İzmir ili ödemiş ilçesinde süt sığırcılığının geliştirilmesi olanakları üzerine bir araştırma. Hayvansal Üretim, 46(1), 8-13.

Kuwornu, J.K.M., Ohene-Ntow, I.D., AsumingBrempong, S. 2012. Agricultural Credit Allocation and Constraint Analyses of Selected Maize Farmers in Ghana. British Journal Economics Management, Trade 2(4):353-374.

DOI: 10.9734/BJEMT/2012/2270

Kumar, A., Singh, D.K., Kumar, P. 2007. Performance of Rural Credit and Factors Affecting the Choice of Credit Sources. Indian Journal of Agricultural Economics. 62(3): 297313.

Mamatzakis, E.C., Staikouras, C. 2020. Testing for the effects of credit crunch on agriculture investment in the EU. Bull Econ Res. 72:434-450.

(doi.org/10.1111/boer.12229)

Mitra, S., Prodhan, M.M.H. 2018. "Factors Determining Credit Access of Tomato Farmers in a Selected Area of Bangladesh". National Journal of Multidisciplinary Research and Development, 3 (1): 406-410.

Moss, C.B., Suh, D.H. 2020. Effect of compliance cost on the supply of bank credit to agriculture: A differential approach. Amer. J. Agr. Econ. 102(2): 713-726; (doi:10.1111/ajae.12074).

Murat, H. 2011. Ege ve Orta Anadolu Bölgesi damızlık sığır yetiştirici birliklerine bağlı süt sığırcılık işletmelerinin ekonomik analizi. Doktora Tezi, Ankara Üniversitesi, Sağlık Bilimleri Enstitüsü, Ankara.

OECD, 2020. Boosting access to credit and ensuring financial inclusion for all in Costa Rica. Organisation for Economic Co-operation and Development. Economics
Department Working Papers No: 1623. ECO/WKP(2020)31. JT03466158. Paris, France.

(https://dx.doi.org/10.1787/86037778en)

Saqip, S.E., Kuwornu, J.K.M., Panezia, S., Ali, U. 2017. Factors determining subsistence farmers' access to agricultural credit in flood-prone areas of Pakistan. Kasetsart Journal of Social Sciences. https://doi.org/10.1016/j.kjss.2017.06.0 01

Sebopetji, T.O., Belete, A. 2009. An application of probit analysis to factors affecting smallscale farmers' decision to take credit: a case study of the Greater Letaba Local Municipality in South Africa. African Journal of Agricultural Research., 4 (8): 718-723.

Semerci, A., Parlakay, O., Çelik, A.D. 2014. Hatay illi Süt Sığırcılığının Ekonomik Analizi. MKÜ BAP Projesi (Proje No:2013-9162) Hatay.

Semerci, A., Çelik, A.D. 2017. Hatay İli Tarım İşletmelerinde Pamuk Üretiminin Ekonomik Analizi". MKÜ BAP Projesi (Proje No:2017-16322) Hatay. 2017.

Semerci, A. Çanakkale İlinde Kanola Üretiminin Ekonomik Analizi". 2019. ÇOMÜ BAP Projesi (Proje No: FHD-2018-2664) Çanakkale. 2019.

Semerci, A.,Everest, B. 2020. Çanakkale İlinde Çeltik Üretiminin Ekonomik Analizi". ÇOMÜ BAP Projesi (Proje No: FBA-2018-2605) Çanakkale. 2020.

Şahin, I., Semerci, A., Kaya, Y.,Çıtak, N. 2010. Ayçiçeği Tarımında Verimlilik ve Destekleme Politikalarının Etkinliğinin Belirlenmesi. (Tarım ve Köyişleri Bakanlığı AR-GE Destekleri Projesi (Proje No: Tagem 08/AR-GE/6 ). 2010.

Tatar, A.M. 2007. Ankara ve Aksaray damızlık sığır yetiştiricileri il birliklerine üye süt sığırcılığı işletmelerinin yapısı ve sorunları. Doktora Tezi, Ankara Üniversitesi, Fen Bilimleri Enstitüsü, Ankara.

Tetyana, S., Petro, Y., Larysa, K., Svitlana, L., Bohdan, K. 2020. Financial support to the agrarian sector of Ukraine. Frontiers Journal of Accounting and Business Research, 2(1): 25-32.

TRT, 2020. Bankalar tarım sektörüne kredi desteğini artırdı.TRT Haber.20 Eylül2020.(erişim:https://www.trthabe r.com/haber/ekonomi/bankalar-tarimsektorune-kredi-destegini-artirdi517394.html, erişim tarihi:23.10.2020) 
Tosun, F., Güneş, E. 2017.Tarım İşletmelerinde Sübvansiyonlu Kredi Kullanımı: Ankara İli Örneği. Tarım Ekonomisi Dergisi. 23 (2): 281-288.

Vural, H. 2017. Tarımsal Finansman. Uludağ Ün. Ziraat Fak. Ders Notları No:113, Bursa.

Yamane, T. 1967. Elementary Sampling Theory, Taro Yamane. Englewood Cliffs, New Jersey: Prentice-. Hall, Inc., pp.405. 1967.

Yan, S. 2020. Research of Financial Support for Agricultural Development. Journal of Business and Economic Development. 5 (1) 21-25. (doi: 10.11648/j.jbed.20200501.13)

Yavuz, F., Dilek, Ş. 2019. Türkiye Tarımına Yeniden Bakış. SETA (Siyaset, Ekonomi Ve Toplum Araştırmaları Vakfı) Yayınları 131, İstanbul. 